\title{
Impact of State Exemption Laws on Small Business Bankruptcy Decision*
}

\author{
Sumit Agarwal \\ Bank of America \\ Mail Stop MD9-978-03-02 \\ 1101 Wootten Parkway \\ Rockville, MD 20814 \\ 301-517-3227 \\ sumit_agarwal@fleet.com \\ Souphala Chomsisengphet** \\ Risk Analysis Division \\ Office of the Comptroller of Currency \\ 150 E Street, SW \\ Washington, D.C. 20919 \\ 202-874-5386 \\ souphala.chomsisengphet@occ.treas.gov \\ Chunlin Liu \\ College of Business Administration \\ University of Nevada, Reno \\ Reno, NV 89557 \\ (775) 784-6993 \\ liuc@unr.edu \\ Lawrence Mielnicki \\ De Lage Landen Financial Services \\ 1111 Old Eagle School Road \\ Wayne, PA 19087 \\ Phone: 610-386-5695 \\ Email: lmielnicki@leasedirect.com
}

JEL Classification: G21, G33, J41

Keywords: Banks, Credit Cards, Small Business Bankruptcy, State Exemption Laws

\footnotetext{
* The authors would like to thank Jim Papadonis and Margaret Burgess for their support of this research project. We would also like to thank Laura Razzolini (editor), Nick Souleles and two anonymous referees for helpful comments. We are grateful to Diana Andrade, Ron Kwolek, and Greg Pownell for excellent research assistance. The views expressed in this research are those of the authors and do not represent the policies or positions of the Office of the Comptroller of Currency, of any offices, agencies, or instrumentalities of the Unites States Government, or of the Bank of America.

** Contact Author.
} 


\begin{abstract}
To provide some insights to the current debate on consumer bankruptcy laws, this article empirically assesses the importance of state bankruptcy exemption levels on the likelihood of small business owners filing for bankruptcy. We accomplish this with the help of a unique panel data set of over 43,000 small business credit card holders over a two-year period from May 2000 - May 2002. We estimate a proportional hazard model of small business bankruptcy and show that for every $\$ 10,000$ increase in a state's homestead exemptions, the risk of small business bankruptcy increases by 8 percent. Moreover, our results also indicate that small business owners will increase the likelihood of filing for bankruptcy by 4 percent with a $\$ 1000$ change in personal property exemption levels.
\end{abstract}




\section{Introduction}

Small businesses are a primary source of employment in the U.S. economy, employing over half of the private sector workforce. Small businesses are responsible for about two-thirds of all net new jobs created. According to the 2002 Small Business Economic Indicators ${ }^{1}$, over 99.7 percent of the 5.7 million firms are classified as small to medium sized businesses. Hence small businesses are a substantial contributor to economic growth in the U.S.

Small business owners enjoy more flexibility and freedom to capitalize on profitable opportunities than their larger-business competitors. Hence, they challenge the larger firms to be more efficient, which is ultimately beneficial to consumers. Unfortunately, small and medium sized businesses have a very low survival rate (SBEI 2002). In 2002 (on the heels of the 2001 recession), there were 550,100 small business births and 584,500 terminations. Both academics and public policy analysts have become increasingly concerned about the success of small businesses.

Recently there has been a surge in small business research, particularly surrounding small business credit supply and demand. Not surprisingly, much of the literature has been focused on changes in lending technologies (relationship ${ }^{2}$ versus scored $^{3}$ ), information processing technologies (soft versus hard), ${ }^{4}$ loan size considerations, ${ }^{5}$ and loan type considerations ${ }^{6}$ as they relate to small business supply and demand. However, very few have actually examined why small and medium sized

\footnotetext{
${ }^{1}$ See, http://www.sba.gov/advo/stats/sbei02.pdf

${ }^{2}$ Studies have looked at the relationship between banks and access to small business lending. Recent studies have looked at the existence of the relationship (Cole 1998), the breadth of the relationship (Mester, Nakamura, and Renault 2001), and the exclusivity of the relationship (Berger, Klapper and Udell 2001 and Ongena and Smith 2001).

${ }^{3}$ Studies have looked at the impact of scored lending of small business loans. Frame, Srinivasan, and Woosley (2001) and Berger, Frame, and Miller (2002) conclude that scored lending tend to increase the portfolio share of small business loans.

${ }^{4}$ See Petersen (2002) and Stein (2002).

${ }^{5}$ Berger, Frame and Miller (2002) conjecture that credit availability, price, and risk for small business loans below and above $100 \mathrm{~K}$ differ in many respects.

${ }^{6}$ Berger and Udell (1995) differentiate between small business loan commitments and lines of credit.
} 
businesses have a very low survival rate. While small businesses are considerably sensitive to macroeconomic and industry risks, it has also been empirically tested that owner and firm characteristics are significantly important in determining the risk of small business default (Agarwal, Chomsisengphet, and Liu 2003).

With bankruptcy filings continuing to rise significantly in recent years, many policy makers are turning their attention to bankruptcy laws. Specifically, Congress is considering reforming personal bankruptcy laws that, if passed, will impact the demand for and supply of both consumer credit and small business funding. White (2001) conclude that this bankruptcy reform could potentially reduce small business ownership but increase the supply of small business credit, and in turn affect the growth of the U.S. economy.

Small business owners have an incentive to file for personal bankruptcy when their indebtedness exceeds the value of their assets because both their personal and business debts can be discharged. ${ }^{7}$ Though the bankruptcy exemption law is primarily designed for consumers, the personal bankruptcy exemption law is a de facto bankruptcy procedure for small business owners because the debt of a non-corporate firm is the personal liability of the entrepreneur/owner (Fan and White 2003). Hence, investigating the potential impact of the exemption law on small business bankruptcy decisions may provide some insight to how the bankruptcy laws should be reformed.

Further, Fan and White (2003) argue that while the expected return to creditors should be lower in states with higher exemption level upon small business shutdown, it is not entirely clear whether lenders will actually shut down a financially troubled small business. While they find empirically that small businesses in high exemption states are more likely to be shutdown, this positive relationship is statistically insignificant. The authors conclude that "additional research will be needed to determine if a significant relationship exists.”

\footnotetext{
${ }^{7}$ It is important that we clarify the difference between default and bankruptcy. An account is declared in default by the lender based either on a violation of one of the loan covenants or sufficiently severe delinquency that the lender begins legal proceedings to recover its funds. Moreover, default does not necessarily lead to bankruptcy, although in most cases borrowers will chose to file for bankruptcy to forestall the lender's legal actions. In this study we will exclusively focus on bankruptcy filers but as indicated earlier since most borrowers in default choose to file for bankruptcy we will validate our empirical estimates on defaulted accounts as well to check for robustness of the results.
} 
With micro level data, we want to test whether small business borrowers act "strategically" in their bankruptcy decision in order to take advantage of the state bankruptcy laws. Our data is a unique panel data set of over 43,000 small business credit card holders over a two-year period (May 2000-May 2002). This panel data includes information on small business bankruptcy filings as well as information on the business owners' financial and credit risk standing. These accounts are small business lines of credit with the following characteristics: the lines are under $\$ 100,000$, contain a personal guarantee by the owner or principal, and were originated using scored lending technology that evaluated the creditworthiness of the business owner and not necessarily the business $^{8}$. Since small business credit card lending is only secured by the personal assets of the owner, this part of credit market theoretically ought to be most affected by exemption provisions and any impact on small business' bankruptcy filing decisions as affected by the exemption laws should be quite noticeable.

To measure the impact of exemption laws on the bankruptcy filings of small businesses we estimate a proportional hazard model. Our empirical results suggest that a rise of $\$ 10,000$ in the homestead exemptions will increase the likelihood of small business owners declaring bankruptcy by 8 percent. Moreover, our results also indicate there is a 4 percent rise in the risk of small business bankruptcy with a $\$ 1000$ increase in personal property exemption levels.

The structure of the rest of the paper is as follows: section 2 provides an overview of the literature; section 3 describes the data and model specification; section 4 presents empirical findings; and section 5 offers concluding remarks.

\section{Literature Review}

White (2003) provides a theoretical and empirical literature review about the U.S personal bankruptcy law. There are two personal bankruptcy procedures available to individuals in the United States. Debtors are allowed to choose between them. Under a Chapter 7 filing, unsecured debts such as credit card debt, installment loans, medical

\footnotetext{
${ }^{8}$ Though it might appear that these loans are originated as consumer credit but they are managed as small business loans.
} 
bills, and damage claims are discharged. Owners are not obliged to use any of their future earnings to repay their debt, but they must turn over all their assets above a certain level of state exemption (homestead and property) to the bankruptcy trustee. Since exemption varies widely across states, debtors residing in states with relatively higher exemptions will be able to retain more of their assets. Under a Chapter 13 filing, debtors do not have to give up any assets, but they must offer a plan to repay a portion of their debt with future income, usually over three to five years. Hynes (1998) describes Chapter 13 as the consumer analog of Chapter 11 reorganization. While debtors have a choice between Chapters 7 and 13, filers have a financial incentive to choose Chapter 7 whenever their assets are less than their state's exemption, and thus can avoid repaying their debts completely (also see Fan and White 2003).

Homestead and personal property exemptions provide debtors in a bankruptcy filing with relief from creditors. Thus, discharging of debts provides debtors with a chance for a "fresh start". Homestead exemptions vary widely: from zero in two states to unlimited in seven states. About one-third of the states also allow their residents to choose between federal bankruptcy exemptions and state exemptions. ${ }^{9}$

Personal property exemptions also vary widely. For instance, Texas has the most generous personal property exemption level of $\$ 30,000$, whereas Hawaii only allows $\$ 2,000$. Many states also allow married couples that file for bankruptcy to take higher exemptions, usually double.

Below, we review the literature on the impact of personal bankruptcy exemptions on consumer credit as well as small business credit.

\subsection{Bankruptcy Exemptions and Household Credit}

According to White (2003), "Bankruptcy is an important aspect of consumer credit markets, because whether consumers repay or default on their loans depends on whether the legal system punishes debtors who default and, if so, how severely." In this respect, the U.S. bankruptcy system is especially favorable towards the debtor (see also,

\footnotetext{
9 This is due to the 1978 Congressional attempt to remove the state variation of exemptions. However, a political compromise lead to a bill that granted a debtor with a choice of either the new federal exemptions or state level exemptions.
} 
e.g., Lin and White, 2001). Consistently, the number of personal bankruptcy filings has almost doubled with a short span of seven years (1996-2002) from 700,000 to more than 1,400,000 (see graph 1).

With bankruptcy filings rising significantly in the recent years, researchers are turning their attention to the potential impact of bankruptcy exemption laws on consumer credit markets. A number of empirical studies have focused on the supply of, as well as the demand for, credit. In particular, whether differences in states’ bankruptcy exemption levels affect aggregate household credit (both secured and unsecured) has been studied by Gropp, Scholz and White (1997), Berkowitz and Hynes (1999), Lin and White (2001), Fay, Hurst, and White (2002), Chomsisengphet and Elul (2003), Fan and White (2003), Berkowitz and White (2003), and Agarwal, Liu, Mielnicki (2003).

Gropp et al. (1997) find empirical support for their theoretical argument that in states with high rather than low bankruptcy exemptions, there is more credit rationing because debtors are more likely to default and file for bankruptcy. Berkowitz and Hynes (1999) argue that due to a positive wealth effect, a financially distressed homeowner filing for bankruptcy will be able to retain more of his assets in high exemption states, which would enable him to continue paying his mortgage. Hence, we should expect that in states with generous exemptions, there should be lower risk of mortgage default and increase access to mortgage credit. By contrast, Lin and White (2001) develop a theoretical model that leads them to the opposite conclusion - in states with relatively higher exemptions, there should be more credit rationing in the mortgage market because lenders incur additional costs of default when a foreclosure occurs in conjunction with a bankruptcy filing. Berkowitz and Hynes as well as Lin and White both test their predictions using HMDA data from the mid-1990s. Interestingly, they each find the data supports their respective hypothesis.

Chomsisengphet and Elul (2003) argue that the models of Berkowitz and Hynes as well as Lin and White ignore a very important variable in lending decisions and thus suffer from an omitted variable bias - the credit history of the mortgage applicants. The authors construct a model to show that by ignoring the impact of exemptions on credit scores, lenders will tend to overstate the riskiness of borrowers from high exemption 
states. Thus, a regression that omits the credit score would indeed find that applicants from high-exemption states are more likely to be denied a mortgage. Empirically, Chomsisengphet and Elul show that once they control for credit scores, exemptions are no longer relevant.

In another related study, Agarwal, Liu, and Mielnicki (2003) empirically test whether homestead, personal property, and garnishment exemptions across states play an important part in consumers' decisions to become delinquent and eventually declare bankruptcy on their credit card debt. Their findings indicate that homestead exemption levels are statistically significant in determining an individual's decision to declare bankruptcy. Fay, Hurst, and White (2002) study the household bankruptcy decision using data from the PSID, which includes information on bankruptcy filings. They conclude that households act "strategically" and declare bankruptcy only when the financial benefits outweigh the costs. Furthermore, they find little support for the prediction that households file due to adverse events (unemployment, divorce, etc.) occurring which inturn, reduces households' ability to pay off their loans. ${ }^{10}$ Interestingly, in their study they also include a dummy variable for households owing a business. They argue that selfemployed individuals are less risk averse and consequently have a higher risk for filings. However, their results do not confirm this proposition. Though their paper empirically tests the effect of exemption law on the household bankruptcy decision while controlling for self employed households, they do not explicitly test the effect of exemption law on the small business bankruptcy decision.

\subsection{Bankruptcy Exemptions and Small Business Credit}

Berkowitz and White (2003) argue that personal bankruptcy exemption laws not only apply to individuals but also to small businesses, irrespective of whether they are incorporated or unincorporated. Debts of an unincorporated firm are personal liability to the firm's owner; thus, the firm's debt at bankruptcy is also the owner's debt. On the other hand, an incorporated firm's limited liability implies that the firm's debt is legally distinct from the owner's debt. However, the authors argue that lenders to small firms

\footnotetext{
${ }^{10}$ See Sullivan, Warren, and Westbrook (1989).
} 
generally require that a firm's debt be guaranteed by the owner, and thus lender may not view the incorporated/unincorporated distinction of small businesses as meaningful.

Furthermore, Fan and White (2003) develop an analytical model to show the impact of variation in state exemption levels on creditors' expected return. In particular, the authors show that creditors' expected return is lower in states with relatively higher exemptions because failing firms can protect their assets from creditors by shifting from non-exempt business categories to exempt personal categories. As a result, the authors predict that creditors are more likely to immediately shut down failing firms that are located in states with a high exemption level. However, the authors do not find statistical support for their hypothesis and conclude that additional research is needed.

\section{Data and Methodology}

\subsection{Data}

The data employed in this study is proprietary in nature. The accounts originated at several financial institutions that issue small business credit cards nationally but they are managed at a single institution. The panel data set covers monthly small business information for around 63,014 accounts originated from May 2000 to May 2002. ${ }^{11}$ Most of the businesses are very small; single-family owned, with no formal financial records. Furthermore, most of these small businesses predominantly secure their credit from debt financing as opposed to equity financing (also see, Berger and Udell, 1998). The data set has all the information that was collected at the time of account origination.

In addition, we also have access to all the performance information since May 2000. Hence, if an account originated in May 2000 and the account is still in good standing, then we would have performance data for a 24-months period. Each account's quarterly bureau credit score updates, internal monthly behavior score updates, borrower's self reported personal income at origination, credit limit, default indicators, bankruptcy indicator, and other information that characterize an accounts standing with the creditor. If the account closes and the account holder declares formal bankrupt at any

\footnotetext{
${ }^{11}$ In some cases bankruptcy resolution can take a long time and so it is possible that a 24 months window may be insufficient. However, we still can find interesting results with the current data limitations.
} 
time, then a formal bankruptcy flag is created. Accounts with a flag indicating lost, stolen, never active, closed due to fraud/death status are excluded from the analysis.

Moreover, we include a macroeconomic control for county unemployment rates. Equally important, we also include state homestead and personal property exemption levels and garnishment levels (see Agarwal, Liu, and Mielnicki 2003). For the purpose of this analysis, we have excluded state level social variables such as - divorce, income and health insurance coverage due to partial unavailability of the data for the time period covered. $^{12}$

Since families that rent rather than own a house cannot use the homestead exemption levels, for the purpose of this study we only concentrate on small business owners who own a house. Although, Fan and White (2003) argue correctly that household's can purchase a house at any time before they decide to file for bankruptcy ${ }^{13}$.

Given all the above criteria, the number of accounts is reduced to about 43,324 with 404 bankruptcies. The number of bankruptcies is less than $1 \%$ of all outstanding loans. It is entirely possible that some accounts have defaulted on the loan (180 days past due) but are in the process of or have declared bankruptcy; however, due to the short time frame of our study and the lag in reporting bankruptcy information to the credit bureau and a further lag in updating bureau information at the financial institution, the 404 bankruptcies are deemed to be underestimated. ${ }^{14}$ However, to account for the possibility that some small businesses that are either in the process of or have declared bankruptcy, we also estimate a separate model of small business default. ${ }^{15}$

\footnotetext{
${ }^{12}$ For completeness we did include some of the social variables and estimated the model on a shorter time period (May 2000 - December 2001) and the results are qualitatively the same.

${ }^{13}$ As suggested by the referee, we estimate a separate model with the inclusion of the renters. We interact the renters and owners with the homestead exemption variable. As expected the coefficients for the renters interacted with homestead exemption levels is statistically insignificant while the coefficients for the owners is statistically significant.

${ }^{14}$ However, according to the 2002 SBEI, while personal bankruptcies reached a new record in 2002 small business bankruptcies dropped by $2.1 \%$ from 2001. The SBEI argues that a drop in interest rates, cut in labor force (removing inefficient operations) account for the drop in small business bankruptcies.

${ }^{15}$ In our data set there are 894 accounts that default. Some of them will invariably declare bankruptcy; others might enter into forbearance plans with the lender, while other will simply default without declaring formal bankruptcy. The data set does not lead itself to distinguish borrowers who enter the forbearance plans versus those who default without declaring bankruptcy. Finally, we do not know the percentage loan recovery either in the event of default or bankruptcy.
} 
Both the small business loans and bankruptcy filings are well represented across the U.S. Table 1 reports some of the descriptive statistics. For instance, the average FICO score is 715 with a standard deviation of 55 (a lower FICO score means higher credit risk). The average credit line and the variable interest rates are \$21,000 and $13.4 \%$ respectively. On average, a small business in our data has been in operation for 4.4 years. Finally, we also know that the borrowers in our data set have an average home mortgage debt of \$102,684 and unsecured personal debt of \$12,767.

The data set employed in our study is uniquely rich in comparison to the survey or account origination data employed in past research. As discussed in Gross and Souleles (2002), observing loan-level accounts overtime has several advantages: (i) greater likelihood of having a critical number of observations of even low probability events like bankruptcy; (ii) the time series nature of the data helps model bankruptcy in a dynamic as opposed to static model; and (iii) in contrast to data based on surveys of small businesses, measurement errors are less of a problem.

\subsection{Methodology}

We estimate a duration model for small business bankruptcy to investigate the impact of bankruptcy exemption levels on the decision of small business owners to file for bankruptcy. ${ }^{16}$ Let $\mathrm{B}_{\mathrm{i}, \mathrm{t}}$ indicate whether an account $i$ becomes bankrupt in month $t$. Using the proportional hazard model, we estimate the conditional probability of bankruptcy at time $t$, assuming the consumer is current from inception up to time $t-1$ (Kiefer 1988). For instance, the account could declare bankruptcy in the $18^{\text {th }}$ month, then $\mathrm{B}_{\mathrm{i}, \mathrm{t}}=0$ for month $\mathrm{t}=1, \ldots, 17$ and $\mathrm{B}_{\mathrm{i}, 18}=1$, and the rest of the observations will drop out of the sample. ${ }^{17}$ The main specification would be as follows:

$$
B_{i, t}=h_{0}(t) \exp \left(\beta^{\prime} Z_{i}(t)\right)
$$

\footnotetext{
${ }^{16}$ Shumway (2002) identifies three reasons to using a duration model as opposed to a static model: (i) static models fail to control for firm period risk; (ii) duration models incorporate time varying covariates; and (iii) duration models produce more efficient out-of-sample bankruptcy estimates by utilizing more data.

17 This is also the most common form of incomplete data and is also defined as right censored. Accordingly, all customers start at time $\mathrm{t}=0$ and a customer could drop out of the sample because they close the account in good standing or even stay current till the end of two years without declaring bankruptcy.
} 
where $h_{0}(t)$ is the baseline hazard function at time t (the hazard function for the mean individual i-th sample), we use calendar quarter dummies $\left(\right.$ Time $_{t}$ ) of the account as a proxy for this baseline. $\mathrm{Z}_{\mathrm{i}}(\mathrm{t})$ is a vector of time-varying covariates; $\beta$ is the vector of unknown regression parameters to be estimated; and $\exp \left(\beta^{\prime} \mathrm{Z}_{\mathrm{i}}(\mathrm{t})\right)$ is the exponential distribution specification that allows us to interpret the coefficients on the vector of $\mathrm{Z}$ as the proportional effect of each of the exogenous variables on the conditional probability of "completing the spell," e.g., small business filing for bankruptcy.

The time-varying exogenous variables (known as covariates) that affect a small business owners decision to file for bankruptcy can be specified as follows:

$$
\begin{aligned}
\beta^{\prime} Z_{i, t}= & \beta_{1} U_{i, t-6}+\beta_{2} \text { SIC }_{i}+\beta_{3} \text { OwnerAge }_{i}+\beta_{4} Y I B_{i} \\
& +\beta_{5} X_{i, t-6}+\beta_{6} L_{i}+\varepsilon_{i, t}
\end{aligned}
$$

where $U_{i, t-6}$ denotes county unemployment rates lagged six months. Here, we use county unemployment rates control for state-specific business-cycle effects. Since we are interested in the unemployment rate at the time the account was in good standing and not the time of actual bankruptcy, lagging this variable by six months will avoid any potential endogeniety of unemployment on bankruptcy. The 2-digit $\mathrm{SIC}_{\mathrm{i}}$ represents dummies for various industry classifications and are used to control for any industry specific effects. OwnerAge $_{i}$ designates the age of the small business owner at account origination. $\mathrm{YIB}_{i}$ denotes the years in business dummy. ${ }^{18}$ We include years in business, months on file, quarterly time dummies, and the age of the business owner these variables in the equation to control for cohort, seasoning, time, and demographic differences across small business owners. As discussed in Degryse and Van Cayseele (2000), we use years in business as a

\footnotetext{
${ }^{18}$ We construct dummies as opposed to a continuous variable for years in business because the financial institution used discrete cutoffs of years in business for portfolio management. We construct five dummy variables as follows. YIB_D1 $=1$ else $=0$ - firm has been in business less than 1 year. YIB_D2 $=1$ else $=0$ firm has been in business more than one year but less than 2.5 years. YIB_D3 $=1$ else $=0-$ firm has been in business more than 2.5 years but less than 5 years. YIB_D4=1 else $=0$ - firm has been in business more than 5 years but less than 10 years. Finally YIB_D5 $=1$ else $=0$ - firm has been in business more than 10 years. We also estimate the model with a continuous variable for YIB and the results are the same.
} 
control for time to buildup of public information and months on file as a control for time to buildup of private information. $\mathrm{X}_{i, t-6}$ represents account specific measures of risk. They include: account balance; credit limit; interest rate; internal and external scores; and others. These variables are all lagged by six months to eliminate any potential endogeniety with small business bankruptcy (also see, Gross and Souleles 2002). Finally, $L_{i}$, represents state specific legal variables, including judicial foreclosure, statutory right of redemption, homestead, property and garnishment exemption levels.

\section{Empirical Results}

\subsection{Exemption Laws and Small Business Bankruptcy Decision}

We estimate several combinations and/or lag structures of the above general specification. Specifically, we estimate the model with various lag structures for the credit risk variables: (i) 6 lags, (ii) 12 lags, and (iii) at origination. This helps alleviate any concern that the creditor, on the basis of small business performance, could endogenously change credit risk variables. We also conduct other robustness checks, such as augmenting the data to include discrete set of dummy variables for garnishment, homestead, and personal property exemptions, as discussed in Fan and White (2003). Finally, we also include quadratic terms for the legal (homestead and property exemptions), and credit risk variables (internal and external scores). These variables change the results quantitatively but not qualitatively. In this paper, we present results for only two specifications.

Table 2 presents empirical results on the impact of state exemption levels on the small business bankruptcy decision under two specifications. The main difference between the two models is that the first model assumes that homestead exemptions are continuous, while the second model assumes that they are discrete (as discussed in Fan and White 2003).

Let us first discuss the impact of the credit risk variables (e.g., credit scores, credit line, and APR) on bankruptcy filings. As expected, the negative coefficient of both internal (payment behavior) and external (FICO) scores suggest that a decrease in internal or external scores significantly increases the likelihood of a small business owner filing for bankruptcy. The coefficient for Credit Line is also negative, but statistically 
insignificant. The coefficient for APR is positive and highly significant, implying that small business cards with higher APR have a higher probability of declaring bankruptcy. Some examples of the economic magnitudes of the predictive variables are as follows: a 10 percent drop in the External (FICO) score raises the probability of bankruptcy by 14 percent; while a 1 percentage point rise in the APR raises the probability of bankruptcy by 6 percent.

As for the macro economic effects, the county unemployment rate coefficient is positive but statistically insignificant. We also control for two-digit SIC by using dummy variables, though the results are not reported in the paper, they isolate any industry specific effects. The results reveal that certain firms with two-digit SIC codes have a significantly higher propensity to declare bankruptcy while others have a significantly lower propensity to declare bankruptcy. Specifically, Special trade contractors (SIC=17), Electronic and other electric equipment (SIC=36), General merchandise stores (SIC=53), and Eating and drinking places (SIC=58) have a higher propensity to declare bankruptcy, while Furniture and home furnishing stores ( $\mathrm{SIC}=57)$, Health services (SIC=80) and Social services (SIC=83) have a lower propensity to declare bankruptcy. The coefficients for the SIC codes are jointly significant, implying the presence of industry specific effects.

Next, we control both for calendar time, years in business, and account age. It is worth noting that age of an account could be different than years in business. For instance, an account that has been 2 years in business could originate at the financial institution on the same day as a different account that has been 3 years in business. For a firm with one extra year in business, the margin impact of bankruptcy filing falls by 6 percent. Since one would expect that younger business owners might be less risk averse, we also control for the business owners' age. While we do not report the coefficient values for these variables, they are jointly significant for each variable and directionally intuitive. For example, owners of small businesses that have been in business longer are less likely to file for bankruptcy.

As for one of the main variables of interest, property exemptions are positive and statistically significant for both Models 1 and 2. Although Fan and White (2003) do not consider the property exemptions levels as part of their study, our results indicate that 
small business entrepreneurs from states with high property exemptions are more likely to file for bankruptcy.

As for state homestead exemption levels: in model 1 , we create a continuous variable for the homestead exemption levels; and in model 2, we follow Fan and White (2003) and construct quartiles dummy variables for homestead exemptions to represent each quartile of the distribution except the lowest. For model 2, we also construct a separate dummy for the unlimited homestead exemptions. However, to compare our results to Fan and White, we look at Model 2. The results indicate that that the homestead exemption dummies for the second and third quartile are negative but statistically insignificant. However, the dummies for the fourth quartile and the unlimited exemption states are positive and statistically significant, indicating that small businesses from states with very generous homestead exemptions are more likely to file for bankruptcy. These results imply that small business owners indeed act "strategically" in declaring bankruptcy by taking advantage of the very generous homestead exemptions. ${ }^{19}$

It is also worth noting that despite the differences in methodology (hazard versus random effects probit), time period, and frequency (1993:Q1-1995:Q4 versus 2000:062002:06), data type (survey versus account level), the results of our study and that of Fan and White's (2003) are fairly consistent. However, our study does find that small business owners in states with higher homestead exemptions are significantly more likely to file for bankruptcy. For example, our empirical results suggest that an increase of $\$ 10,000$ in the homestead exemptions will raise the probability of small business owners declaring bankruptcy by 8 percent. Moreover, our results also indicate that small business owners will increase the probability of bankruptcy by 4 percent with a $\$ 1000$ change in personal property exemption levels. These results are estimated using the baseline survival function at the mean values for all other variables and predict the rise in the probability of bankruptcy over a one-year time horizon.

Furthermore, three other legal variables measuring the effect of state foreclosures also have the expected signs: (1) states with statutory right of redemption have higher risk

\footnotetext{
${ }^{19}$ We also estimate a model for small business defaults as opposed to bankruptcies. As discussed in footnote 7, due to the possibility of lags in reporting bankruptcy to the lenders and default being a precursor to bankruptcy we should find similar results. As reported in Appendix A, the results are remarkably similar both qualitatively and quantitatively.
} 
of bankruptcy; however, the coefficient is statistically insignificant; (2) states that require judicial foreclosure extends the foreclosure process, and thereby they should have a lower risk of bankruptcy; however, the estimated coefficient is insignificant; and (3) states that do not allow deficiency judgment should have higher risk of small business filing for bankruptcy, since this prohibits the lender from collecting unpaid balances on personal assets. ${ }^{20}$ Clauretie and Herzog (1990) and Pence (2003) also report similar results. We also control for garnishment allowance in case of bankruptcy. The results indicate that states with high garnishment allowance have lower probability of bankruptcy, albeit the coefficient value is statistically insignificant.

We also include dummy variables for both total secured debt (mortgage, auto, and home equity loans/lines) and total unsecured debt (unsecured lines of credit) of the small business owner as reported at the credit bureau and updated quarterly. We construct five categories for each type of debt. For unsecured debts, the five categories are (i) \$0 to $\$ 1,000$; (ii) $\$ 1,000$ to $\$ 5,000$; (iii) $\$ 5,000$ to $\$ 10,000$; and (iv) greater than $\$ 10,000$. For secured debts, the categories are (i) $\$ 0$ to $\$ 10,000$; (ii) $\$ 10,000$ to $\$ 25,000$; (iii) $\$ 25,000$ to $\$ 50,000$; and (iv) greater than $\$ 50,000$. Although we tried several other cut off amounts, including continuous variables, for both secured and unsecured debt, the results did not change substantially. Our results show that small business owners with higher unsecured (secured) debt are more (less) likely to declare bankruptcy; the coefficients for these variables are jointly significant.

An increase in bankruptcy exemptions not only provides small business owners with wealth protection when their businesses fail, but may encourage small business owners to take higher risk in their business decisions and induce lenders to charge higher interest rates. It will be interesting to know (i) whether those small business owners living in states with higher exemptions indeed take more risky investment projects, and (ii) whether lenders charge higher APR or offer lower credit lines at account origination for those small business owners who live in higher exemptions states. The following sections provide some insights to these important questions.

\footnotetext{
${ }^{20}$ We define the deficiency judgment variables as 1 if the state does not allow deficiency judgment.
} 


\subsection{Exemption Laws and Small Business Investment Decision}

Due to the lack of adequate information about the choice of small business owner's investment project decision, we use the volatility of an account's payment during the study period as a proxy for the riskiness of the project. As documented within the small business literature (e.g. Agarwal, Chomsisengphet, Driscoll (2004) and Strahan (1999)), small businesses demand lines of credit to meet recurring expenses as opposed to financing long-term investments. Hence, we would expect a low-risk business owner to draw up and down the line fairly uniformly. However, a high-risk business might experience higher payment volatility. Hence, we use the following regression model to determine whether exemption levels affect the riskiness of small business projects.

$$
V_{i}=\beta_{1} X_{i}+\beta_{2} \operatorname{SIC}_{i}+\beta_{3} Y I B_{i}+\beta_{4} \text { OwnerAge }_{i}+\beta_{5} L_{i}+\varepsilon_{i}
$$

Where $i$ represents a small business. $V_{i}$ is the standard deviation of monthly payment as ratio of total outstanding debt over a two years period. ${ }^{21} \mathrm{Z}_{i}$ are the determinants of customer credit risk at account origination (external credit score, bureau debt, bureau credit line), $S I C_{i}$ represents dummies for various industry classifications. $Y I B_{i}$ denotes years in business. OwnerAge ${ }_{i}$ designate the age of the small business owner at account origination. Finally, $L_{i}$, represents state specific legal variables like homestead and property exemptions.

Table 3 reports the results. SIC and OwnerAge dummies are not reported. Some of the SIC dummies are statistically significant and indicate that higher risk industries are positively correlated with payment volatility. OwnerAge dummies are statistically insignificant. Both APR and external score are statistically significant and positive borrowers with a higher APR and higher credit quality have higher payment volatility. Finally, homestead and property exemptions are statistically insignificant, indicating that business owners from states with relatively higher exemptions do not invest in riskier investment projects.

\subsection{Impact of Exemption Laws on APR and Credit Lines}

\footnotetext{
${ }^{21}$ We also estimate the model with the dependent variable being the standard deviation of monthly purchases. The results are qualitatively the same.
} 
Finally, we conduct additional analysis to determine whether lenders will charge higher interest rates or offer lower credit lines at account origination to small business owners who live in higher exemption states. Specifically, we estimate the following linear regression model to determine the impact of exemption levels on interest rates and lines of credit at account origination.

$$
Y_{i}=\beta_{1} X_{i}+\beta_{2} S I C_{i}+\beta_{3} Y I B_{i}+\beta_{4} L_{i}+\varepsilon_{i}
$$

where $i$ represent a small business. $Y_{i}$ can either be APR or Line Amount at account origination. Definitions of other variables $\left(X_{i}, S I C_{i}, Y I B_{i}, L_{i}\right.$, $)$ in the regression are the same as in equation (2).

Table 4 presents the results for two different models that test the impact of bankruptcy exemption laws on APR and line amount at account origination. The results show that a higher credit score leads to lower APR and higher line amount. A low bureau debt and high bureau credit line leads to lower APR and higher line amount. A low bureau debt and high bureau credit line are indications of high credit worthiness of the business owner. Finally, the coefficient for years in business also has statistically significant impact on APR and line amount. The longer the owner is in business, the lower is the APR higher is the line amount. ${ }^{22}$ These results are consistent with the riskbased pricing hypothesis proposed in Edelberg (2003).

On the other hand, both homestead and property exemptions are statistically insignificant and do not help predict either APR or line amount, implying that the lender may not endogenously determine the APR or line amount based on applicants' residence. These results are consistent with Berkowitz and White (2003), who also conclude that variations in bankruptcy exemption levels do not cause loan size to be smaller or interest rates to rise. These are several possible explanations for these results. The first proposed by Berkowitz and White (2003) states that financial institutions may practice extreme form of credit rationing, i.e. completely decline credit. Another possible explanation could be that credit rationing along state lines could be considered "redlining" and deemed illegal.

\footnotetext{
${ }^{22}$ Since years in business captures the built up of public information as discussed in Degryse and Van Cayseele (2000), it implies that the longer the owner is in business the lower are their chances of default and bankruptcy.
} 
Finally, there is concern that credit scores may be subject to the effect of exemption laws and in turn, may be the reason that the coefficients for the exemption laws are statistically insignificant. To address this concern, we estimate the correlation between scores and exemptions. The correlation coefficient of -0.13 (p-value $=0.0403$ ) is marginally significant at the conventional 5\% level, suggesting that higher exemption states have lower credit scores, on average. These results are consistent with Chomsisengphet and Elul (2003), who argue that credit scores for consumers are lower, on average, in states with higher exemptions. Therefore, the authors point out that studies which find exemption levels to have significant impact on mortgage applications suffer from an omitted variable bias, e.g., credit scores. However, this study is not looking at the loan origination decision but the impact of exemptions on booked accounts. Finally, scores may not adequately capture the impact of exemptions since they are statistically significant in determining the small business bankruptcy decision as discussed earlier.

\section{Conclusion}

Over the past five years, there has been tremendous interest in the area of small business credit and default as a result of dramatic rise in personal bankruptcy filings. Advocates of the "strategic" model attempting to explain the rise in bankruptcy filings argue that the surge in bankruptcy filings is in part due to higher homestead and personal property exemption levels that enable those in bankruptcy filings to retain more of their assets. The purpose of this study is to provide an answer to the question: do state exemption laws affect the decision of small business owners to file for bankruptcy?

Using panel data for over 43,000 small business credit card lines of credit that originated using scored lending technology under $\$ 100,000$, we estimate proportional hazard model to assess the effect of state exemption laws on small business bankruptcy decision. Our empirical results suggest that a rise of $\$ 10,000$ in the homestead exemptions will increase the probability of small business owners declaring bankruptcy by 8 percent. Moreover, our results also indicate that small business owners will increase 
the probability of bankruptcy by 4 percent with a $\$ 1000$ change in personal property exemption levels.

Our study - though the first to use loan level panel data to empirically measure the impact of state exemption laws on small business bankruptcy decision - has several limitations. The results only look at the small business credit cards for scored customers under $\$ 100,000$ lines of credit from a single financial institution. These results could vary due to institutional, lending technology, loan size, as well as loan type differences (see e.g., Agarwal, Chomsisengphet, and Liu 2003). Despite the above limitations, we think that these results make a significant contribution to the literature on exemption laws and small business bankruptcy. Our results suggest that the small business owners might act "strategically" to take advantage of exemption laws in their decision to file for bankruptcy. 


\section{References}

Agarwal, S., S. Chomsisengphet, and J. Driscoll. 2004. Loan commitments and private firms. Unpublished paper, Finance and Economics Discussion Series 2004-27, Board of Governors of the Federal Reserve System.

Agarwal, S., S. Chomsisengphet, C. Liu. 2003. Determinants of small business default: Owner versus firm characteristics. Unpublished Paper, University of Nevada, Reno.

Agarwal, S., C. Liu, and L. Mielnicki. 2003. Exemption laws and consumer delinquency and bankruptcy behavior: An empirical analysis of credit card data. Quarterly Review of Economics and Finance 43(2):273-289.

Berger, A. N., W. S. Frame, and N. H. Miller. 2002. Credit scoring and the availability, price, and risk of small business credit. Unpublished paper, Federal Reserve Bank of Atlanta, Working Paper 2002-6.

Berger, A. N., L. F. Klapper, and G. F. Udell. 2001. The ability of banks to lend to informationally opaque small businesses. Journal of Banking and Finance 25(12): 2127-2167.

Berger, A. N., and G. F. Udell. 1995. Relationship lending and lines of credit in small firm finance. Journal of Business 68(3):351-381.

Berkowitz, J., and R Hynes. 1999. Bankruptcy exemptions and the market for mortgage loans. Journal of Law and Economics 42(2):809-830.

Berkowitz, J., and M. J. White. 2003. Bankruptcy and small firms' access to credit. The RAND Journal of Economics. In Press.

Chomsisengphet, S., and R. Elul. 2003. Personal bankruptcy exemptions, credit history and the mortgage market. Unpublished paper, Office of the Comptroller of the Currency

Clauretie, T. M. and T. N. Herzog. 1990. The effect of state foreclosure laws on loan losses: Evidence from the mortgage insurance industry. Journal of Money, Credit and Banking 22(2):221-233.

Cole, R. A. 1998. The importance of relationships to the availability of credit. Journal of Banking and Finance 22:959-977. 
Degryse, H., and P. V. Cayseele. 2000. Relationship lending within a bank-based system: Evidence from European small business data. Journal of Financial Intermediation 9: 90-109.

Edelberg, W. 2003. Risk-based pricing of interest rates in household loan markets. Unpublished paper, Federal Reserve Board.

Fan, W., and M. J. White. 2003. Personal bankruptcy and the level of entrepreneurial activity. Journal of Law and Economics. In Press.

Fay, S., E. Hurst, and M. J. White. 2002. The household bankruptcy decision. American Economic Review 92(30):706-718.

Frame, W. S., A. Srinivasan, L. Woosley. 2001. The effect of credit scoring on small business lending. Journal of Money Credit and Banking 33(3):813-825

Gropp, P.J., K. Scholz, and M. J. White. 1997. Personal bankruptcy and credit supply and demand. Quarterly Journal of Economics 112(1):217-251.

Gross, D. B., and N. S. Souleles. 2002. An empirical analysis of personal bankruptcy and delinquency. Review of Financial Studies 15(1):319-347.

Hynes, R. M. 1998. Three essays on exemptions and consumer bankruptcy. Ph.D. Thesis, University of Pennsylvania.

Kiefer, N. M. 1988. Economic duration data and hazard functions. Journal of Economic Literature 26:646-679.

Lin, Y. E., and M. J. White. 2001. Bankruptcy and the market for mortgage and home improvement loans. Journal of Urban Economics 50:138-162

Mester, L. J., L. I. Nakamura, and M. Renault. 2001. Checking accounts and bank monitoring. Unpublished paper, Wharton Financial Institutions Center.

Ongena, S., and D. Smith. 2001. Empirical evidence on the duration of banking relationships. Journal of Financial Economics 61:449-475.

Pence, K. 2003. Foreclosing on opportunity: State laws and mortgage credit. Unpublished paper, Federal Reserve Board.

Petersen, M. A. 2002. Information: Hard and soft. Unpublished paper, Northwestern University.

Shumway, T. 2001. Forecasting bankruptcy more accurately: A simple hazard model. Journal of Business 74(1):101-124 
Sullivan, T. A., E. Warren, and J. L. Westbrook.1989. As we forgive our debtors. New York: Oxford University Press.

Stein, J. 2002. Information production and capital allocation: Decentralized versus hierarchical firms. Journal of Finance 57:1891-1922.

Strahan, P. E. 1999. Borrower risk and the price and nonprice terms of bank loans. Unpublished paper, Federal Reserve Bank of New York.

White, M. J. 2003. Bankruptcy and consumer credit in the U.S. Unpublished paper, University of California - San Diego.

White, M. J. 2001. Bankruptcy and Small Business. Regulation 18:18-20. 
Table 1: Descriptive Statistics*

\begin{tabular}{c|c|c}
\multicolumn{3}{c}{ (Means and Standard Deviations respectively) } \\
\hline External (FICO) Score & 715 & 55 \\
Internal (Payment Behavior) Score & 723 & 78 \\
Credit Line Amount & $\$ 21,000$ & $\$ 6,058$ \\
Total Unsecured Debt & $\$ 12,767$ & $\$ 17,760$ \\
Total Mortgage Debt & $\$ 102,685$ & $\$ 160,800$ \\
APR & $13.40 \%$ & $5.36 \%$ \\
Years in Business & 4.40 & 4.70 \\
County Unemployment Rate & $5.10 \%$ & $2.14 \%$ \\
\hline
\end{tabular}

- This table provides summary statistics for some of the key variables. Higher scores (external and internal) imply lower probability of default. Unsecured and secured debt measures total debt as reported by the credit bureau.

Table 2: Proportional Hazard Model Measuring the Response of State Exemptions Laws on Small Business Bankruptcy*

\begin{tabular}{|c|c|c|c|c|c|c|}
\hline \multirow[b]{2}{*}{ Independent Variables } & \multicolumn{3}{|c|}{ Model 1} & \multicolumn{3}{|c|}{ Model 2} \\
\hline & Coeff Value & Std. Err & p-value & Coeff Value & Std. Err & $\mathrm{p}$-value \\
\hline External Score $_{t-6}$ & -0.0091700 & 0.0009893 & $<.0001$ & -0.0091900 & 0.0009928 & $<.0001$ \\
\hline Internal Score $t_{-6}$ & -0.0024200 & 0.0002159 & $<.0001$ & -0.0024100 & 0.0002165 & $<.0001$ \\
\hline Line Amount $t_{-6}$ & -0.0000077 & 0.0000126 & 0.5415 & -0.0000082 & 0.0000126 & 0.5174 \\
\hline $\mathrm{APR}_{\mathrm{t}-6}$ & 0.2952300 & 0.0251500 & $<.0001$ & 0.2952000 & 0.0252200 & $<.0001$ \\
\hline Homestead 5K-10K & & & & -0.0096700 & 0.2455700 & 0.9686 \\
\hline Homestead 10K-25K & & & & -0.0235100 & 0.0190800 & 0.14304 \\
\hline Homestead $25 \mathrm{~K}+$ & & & & 0.1870900 & 0.0702400 & 0.04361 \\
\hline Homestead 1Million & & & & 0.5069200 & 0.2023300 & 0.0245 \\
\hline Homestead & 0.0000005 & 0.0000002 & 0.0293 & & & \\
\hline Property & 0.0000392 & 0.0000126 & 0.0018 & 0.0000418 & 0.0000139 & 0.0026 \\
\hline Deficiency Judgment & 0.3252700 & 0.1712000 & 0.0574 & 0.4039400 & 0.2117400 & 0.0564 \\
\hline Garnishment & -0.0085800 & 0.0085800 & 0.3173 & -0.0108900 & 0.0110000 & 0.3219 \\
\hline Statutory Right of Redemption & -0.0139100 & 0.2173300 & 0.949 & -0.0205000 & 0.2336800 & 0.9301 \\
\hline Judicial Foreclosure Required & 0.0004191 & 0.1537200 & 0.9978 & 0.0183900 & 0.1588500 & 0.9078 \\
\hline Unsecured Debt 1K-5K & 0.0167900 & 0.2147600 & 0.9377 & 0.0193400 & 0.2149500 & 0.9283 \\
\hline Unsecured Debt 5K-10K & 0.0619600 & 0.2354300 & 0.7924 & 0.0567200 & 0.2355300 & 0.8097 \\
\hline Unsecured Debt $>10 \mathrm{~K}$ & 0.4894300 & 0.1745700 & 0.0051 & 0.4861700 & 0.1746900 & 0.0054 \\
\hline Mortgage Debt 10K-25K & -0.0125800 & 0.1892300 & 0.947 & -0.0081300 & 0.1901500 & 0.9659 \\
\hline Mortgage Debt 25K-50K & -0.2253400 & 0.2373900 & 0.3425 & -0.2321600 & 0.2378700 & 0.3291 \\
\hline Mortgage Debt $>50 \mathrm{~K}$ & -0.3247500 & 0.1384800 & 0.019 & -0.3244600 & 0.1384400 & 0.0191 \\
\hline County Unemployment $t_{-6}$ & 0.0279800 & 0.0269300 & 0.2988 & 0.0280100 & 0.0270300 & 0.3001 \\
\hline 2 Digit SIC Dummies & Yes & & & Yes & & \\
\hline Years In Business Dummies & Yes & & & Yes & & \\
\hline Small Business Owner Age Dummies & Yes & & & Yes & & \\
\hline Quarter Dummy & Yes & & & Yes & & \\
\hline Log Likelihood/Pseudo R-square & 2,123 & 0.34 & & 2,139 & 0.36 & \\
\hline Number of Observations/Bankruptcy & 215,203 & 404 & & 215,203 & 404 & \\
\hline
\end{tabular}

* The table reports results of a hazard model of small business bankruptcy using monthly account level data from May 2000 to May 2002. Explanatory variables include account-specific risk factors - external score, internal score, APR, line amount, age (owner and firm), total unsecured and secured debt; legal factors - deficiency judgment, garnishment, statutory right of redemption, judicial foreclosure requirement, property and homestead exemptions; macro risk factors - county unemployment; industry risk factors - SIC dummies. Subscript t-6 represents the control variables six months prior to bankruptcy. 
Table 3: Response of State Exemptions Laws on Business Payment Volatility

Over a Two Years Period*

\begin{tabular}{c|ccc}
\hline & Coeff. Value & Std. Err. & t-stat \\
\hline Intercept & -2.8664400 & 3.3653260 & -0.85 \\
Credit Line & -0.0000118 & 0.0000246 & -0.48 \\
Total Bureau Debt & 0.0000012 & 0.0000008 & 1.47 \\
Years in Business & 1.2008140 & 0.8459816 & 1.42 \\
Years in Business (square) & -0.2255190 & 0.4457271 & -0.51 \\
Property Exemptions & 0.0000273 & 0.0000222 & 1.22 \\
Homestead Exemptions & 0.0000001 & 0.0000001 & 0.25 \\
External Score & 0.0067415 & 0.0028680 & 2.35 \\
APR & 0.0394364 & 0.0178757 & 2.21 \\
SIC Dummies & Yes & \\
Age Dummies & \multicolumn{3}{|c}{0.07} \\
Adj. R-Square & 43,324 \\
Number of Obs. & \multicolumn{3}{c}{} \\
\hline
\end{tabular}

* The table reports results of an ordinary least square regression of payment volatility at account origination. The key explanatory variables include property and homestead exemption levels.

Table 4: Response of State Exemptions Laws on APR and Line Amount at Account Origination*

\begin{tabular}{|c|c|c|c|c|c|c|}
\hline & \multicolumn{3}{|c|}{ Dependent Variable: APR } & \multicolumn{3}{|c|}{ Dependent Variable: Line Amount } \\
\hline & Coeff. Value & Std. Err. & t-stat & Coeff. Value & Std. Err. & t-stat \\
\hline Intercept & 16.7095000 & 0.61166000 & 27.32 & -14551.00000 & 463.04374 & -31.42 \\
\hline Bureau Credit Line & -0.00000005 & 0.00000011 & -0.44 & 0.00037 & 0.00008 & 4.4 \\
\hline Bureau Debt & 0.00000784 & 0.00000178 & 4.42 & -0.02456 & 0.00136 & -18.09 \\
\hline Years in Business & 0.61203000 & 0.23049000 & 2.66 & 1402.63177 & 176.46263 & 7.95 \\
\hline Years in Business (square) & -1.21081000 & 0.10982000 & -11.03 & 2891.87999 & 83.15499 & 34.78 \\
\hline Property Exemptions & -0.00004308 & 0.00006200 & -0.69 & 0.02279 & 0.04730 & 0.48 \\
\hline Homestead Exemptions & -0.00000060 & 0.00000052 & -1.15 & 0.00002 & 0.00009 & 0.26 \\
\hline External Score & -0.01368000 & 0.00081600 & -16.76 & 30.57888 & 0.61806 & 49.48 \\
\hline SIC Dummies & Yes & & & Yes & & \\
\hline Adj. R-Square & 0.02 & & & 0.14 & & \\
\hline Number of Observations & 43,324 & & & 43,324 & & \\
\hline
\end{tabular}

* The table reports results of ordinary least square regressions of APR and credit line amount at account origination. The key explanatory variables include property and homestead exemption levels. 


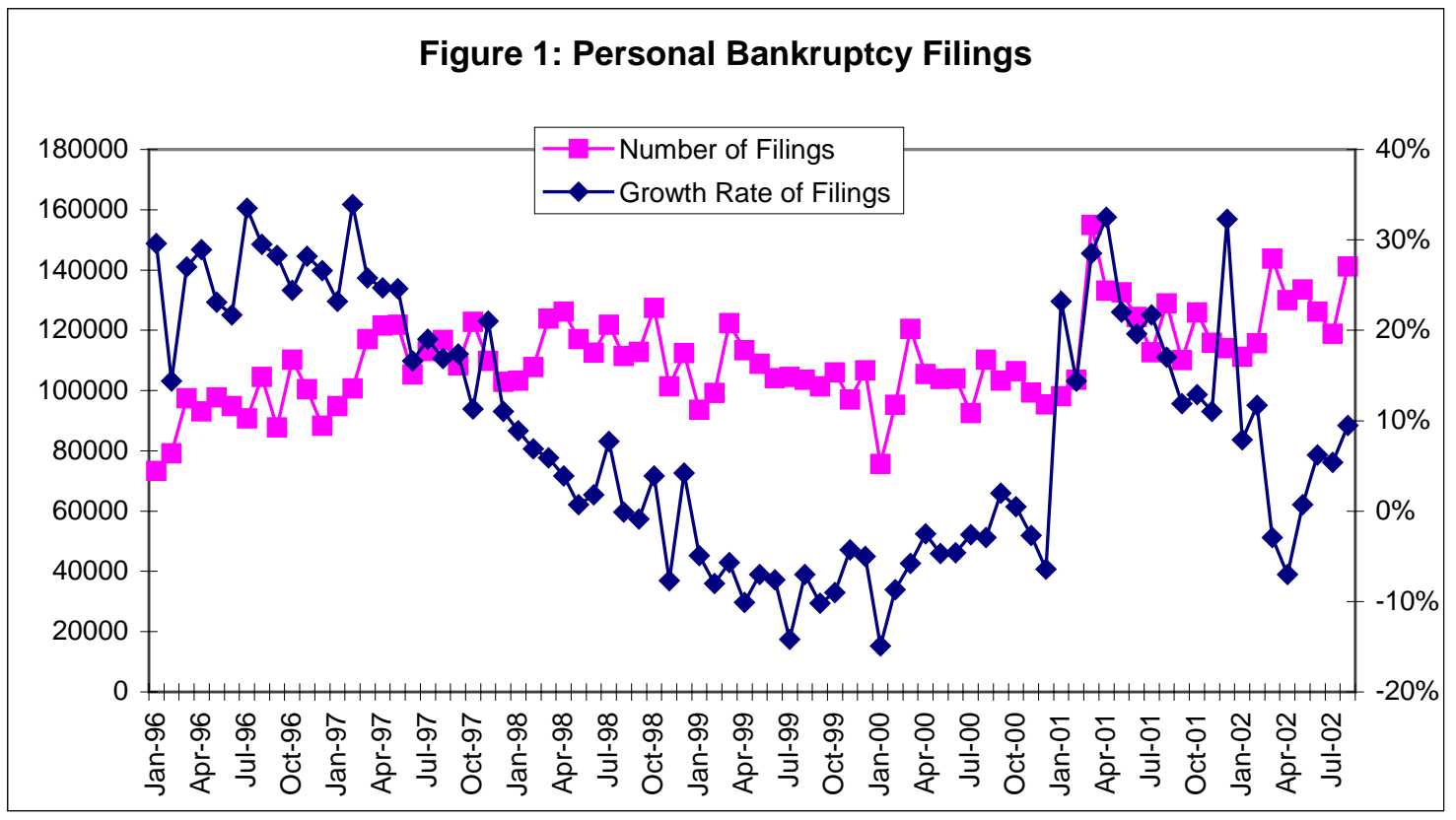

Source: American Bankruptcy Institute and author calculations. 
Appendix: Proportional Hazard Model Measuring the Response of State Exemptions Laws on Small Business Default*

\begin{tabular}{|c|c|c|c|c|c|c|}
\hline \multirow[b]{2}{*}{ Independent Variables } & \multicolumn{3}{|c|}{ Model 1} & \multicolumn{3}{|c|}{ Model 2} \\
\hline & Coeff Value & Std. Err & $\mathrm{p}$-value & Coeff Value & Std. Err & p-value \\
\hline External Score ${ }_{t-6}$ & -0.0091500 & 0.0009886 & $<.0001$ & -0.0091900 & 0.0009938 & $<.0001$ \\
\hline Internal Score ${ }_{t-6}$ & -0.0024300 & 0.0002166 & $<.0001$ & -0.0024200 & 0.0002172 & $<.0001$ \\
\hline Line Amount $\mathrm{A}_{\mathrm{t}-6}$ & -0.0000070 & 0.0000126 & 0.5787 & -0.0000073 & 0.0000126 & 0.5646 \\
\hline $\mathrm{APR}_{\mathrm{t}-6}$ & 0.2972100 & 0.0252900 & $<.0001$ & 0.2962500 & 0.0253300 & $<.0001$ \\
\hline Homestead 5K-10K & & & & -0.1597600 & 0.0544200 & 0.0074 \\
\hline Homestead 10K-25K & & & & -0.0999100 & 0.2938100 & 0.7338 \\
\hline Homestead $25 \mathrm{~K}+$ & & & & 0.0665200 & 0.0364930 & 0.0802 \\
\hline Homestead 1Million & & & & 0.4280500 & 0.1635300 & 0.0034 \\
\hline Homestead & 0.0000005 & 0.0000002 & 0.0251 & & & \\
\hline Property & -0.0000343 & 0.0000135 & 0.0109 & -0.0000376 & 0.0000145 & 0.0095 \\
\hline Deficiency Judgment & 0.4087100 & 0.1899300 & 0.0314 & 0.4436100 & 0.2151300 & 0.0392 \\
\hline Garnishment & -0.0051100 & 0.0093200 & 0.5839 & -0.0100700 & 0.0111300 & 0.3658 \\
\hline Statutory Right of Redemption & -0.0157500 & 0.2181100 & 0.9424 & 0.0187600 & 0.2369400 & 0.9369 \\
\hline Judicial Foreclosure Required & -0.2211100 & 0.2671100 & 0.4078 & -0.2328600 & 0.2878000 & 0.4185 \\
\hline Unsecured Balance $1 \mathrm{~K}-5 \mathrm{~K}$ & 0.0144200 & 0.2147500 & 0.9464 & 0.0138900 & 0.2150200 & 0.9485 \\
\hline Unsecured Balance $5 \mathrm{~K}-10 \mathrm{~K}$ & 0.0619200 & 0.2354200 & 0.7925 & 0.0594800 & 0.2355300 & 0.8006 \\
\hline Unsecured Balance $>10 \mathrm{~K}$ & 0.4983700 & 0.1746500 & 0.0043 & 0.4934800 & 0.1746900 & 0.0047 \\
\hline Secured Debt 10K-25K & -0.0046100 & 0.1893200 & 0.9806 & -0.0075600 & 0.1900400 & 0.9683 \\
\hline Secured Debt 25K-50K & -0.2238300 & 0.2373000 & 0.3456 & -0.2352900 & 0.2379400 & 0.3227 \\
\hline Secured Debt $>50 \mathrm{~K}$ & -0.3293700 & 0.1386000 & 0.0175 & -0.3292100 & 0.1386100 & 0.0175 \\
\hline County Unemployment $t_{t-6}$ & 0.0280400 & 0.0230600 & 0.2430 & 0.0282700 & 0.0241000 & 0.2493 \\
\hline 2 Digit SIC Dummies & Yes & & & Yes & & \\
\hline Years In Business Dummies & Yes & & & Yes & & \\
\hline Small Business Owner Age Dummies & Yes & & & Yes & & \\
\hline Quarter Dummy & Yes & & & Yes & & \\
\hline Log Likelihood/Pseudo R-square & 2,231 & 0.35 & & 2,319 & 0.37 & \\
\hline Number of Observations/Defaults & 219,993 & 894 & & 219,993 & 894 & \\
\hline
\end{tabular}

* The table reports results of a hazard model of small business default using monthly account level data from May 2000 to May 2002. Explanatory variables include account-specific risk factors - external score, internal score, APR, line amount, age (owner and firm), total unsecured and secured debt; legal factors - deficiency judgment, garnishment, statutory right of redemption, judicial foreclosure requirement, property and homestead exemptions; macro risk factors - county unemployment; industry risk factors - SIC dummies. Subscript t-6 represents the control variables six months prior to default. 